\title{
Evaluation of Male Presence in Small Christian Communities in Kapcherop Parish, Diocese of Eldoret, Kenya
}

\author{
Richard Kimeli* \\ Department of Philosophy, Religion and Theology, School of Arts and Social Sciences, Moi University, P. O. Box 3900- \\ 30100, Eldoret, Kenya
}

\section{*Corresponding Author}

Richard Kimeli

\section{Article History}

Received: 10.09 .2020

Accepted: 18.09 .2020

Published: 08.10.2020

\begin{abstract}
When Pope John Paul II visited Kenya in 1995 to launch Ecclesia in Africa, he reiterated the resolve of the gathering to implement a family Church. The communities, according to this papal teaching, should be those that pray and listen to God's word, encourage the members themselves to take up responsibilities, learn to live like Christ and reflect human problems in the light of the Gospel. The study evaluated the presence of males in small Christian communities in Tenden Sub-Parish, Kapcherop Parish, Diocese of Eldoret, Kenya. The study adopted a descriptive approach. It used purposive and stratified sampling to identify 12 key informants, comprising priests, Deacons, Seminarians, and SCC leaders. The study employed questionnaires and interviews to collect data. Secondary data was generated from various libraries. Generally, there is low male participation in SCCs. The main reason given was the perception that SCCs tended to subvert the traditional dominant role of males in the Marakwet society. Therefore, SCCs need to undertake awareness on the church-intended roles of SCCs.
\end{abstract}

Keywords: Male, Men, Presence, Small Christian Communities, Tenden Sub-Parish, Kenya.

\section{INTRODUCTION}

Small Christian Communities (SCCs) were initiated when Agnelo Rossi started an evangelization movement that used lay catechists to cover areas not reached by the clergy. In this case, they emerged from pastoral practice. John Guiney has written a reflection on SCCs in the Latin America. He observes that in the SCCs are three essential expectations: "To be effective means to bring people into psychological, social and ecclesiological communion with one another and with the entire Church" [1].

At a Puebla meeting in 1979, the Catholic bishops discussed SCCs. They saw SCCs as avenues where the Church realizes its spirit of communion. Leonardo Boff argues that SCCs truly constitute Church as a sacrament and, as such, it is a mystery of communion of God with human beings and of human beings among themselves [1]. From this reflection, communion between members stands out prominently. SCCs invite all family members to participate without reservation. Once members understand the impetus behind the SCCs, then they shall do all they can to cultivate and sustain it. It is evident that, through SCCs, members look for something extra to rejuvenate their faith apart from mass and daily prayer in the Church. These people no longer condone impositions from their leaders. They want to be freed from doctrinal packages so as to participate freely (Personal Communication, Catechist, Chemalal Eldoret, 2019). Some members of the SCCs respond that, unlike the Catholics, evangelicals had better chances of being esteemed and recognized as individuals in their Churches than in a highly centralized and structured body like the Catholic set up. The above atmosphere, though not generally observed, exemplifies a scenario in which members of the Church wish to be part of the growth process of SCCs.

In the Vatican II Council of 1965, SCCs were given a new meaning as faith Communities of prayer, Bible study and reflection. Contemporary historians trace the birth of SCCs to as far back as 1943 and 1956 in Chile and Brazil, respectively. From the Latin America, this idea of SCCs spread to the entire USA and other parts of the world, including

Copyright (C) 2020: This is an open-access article distributed under the terms of the Creative Commons Attribution license which permits unrestricted use, distribution, and reproduction in any medium for non commercial use (NonCommercial, or CC-BY-NC) provided the original author and source are credited. 
Canada and Africa. Their beginning was triggered by an acute shortage of priest, refugee problems and the need to face life challenges together. Problems of racism and oppression, common to date in the Latin America, Europe and USA, made SCC members to seek ways and means to assist one another. Racism and social as well as economic discrimination has not been overcome by the Church and remains a big obstacle to Christianity. SCCs attempt to live through sharing and concern for the other. This ideal is at times difficult but this is the mission of the Church seen as the basic unit of the entire institution mandated to preach Christ.

The Symposiums of Episcopal Conferences in Africa and Madagascar (SECAM) convened several meetings in parts of Africa to educate people within the region on the need to form SCCs. Bishops of Eastern Africa had envisioned tremendous challenges mainly due to shortage of personnel in the pastoral field. In 1973, AMECEA convened a study conference in St. Thomas Aquinas Seminary, Nairobi, to plan for the Church in Eastern Africa beyond 1980. This desire was inspired by the need to live fully and in a better way as Christians. After the 1974 synod of all Bishops in Rome, Pope Paul VI highlighted new approaches to evangelization. Evangelii Nuntiandi admits the difficulty with which people deal with the entire whole Church compared to the ease of dealing with neighbours [2]. The encyclical lays out the role of all family members who find themselves in a suitable milieu where faith can be lived and practiced. Unfortunately, again, this ideal comes with great difficulty.

The Bishops, in two of their meetings in 1976 and 1979, both in Zomba, Malawi, stressed the need to build SCCs in their dioceses. Pope Paul VI had mentioned this before in his encyclical letter Evangelization in the Modern world (Evangelii Nuntiandi) of 1975. During this time, the main focus was on helping the poor and working for the development of people [2]. Again, the focus was on the universal responsibility of the entire family without reservation. This idea comes out so well in The Nature of Basic Ecclesial Communities by Joseph Healey where he attempts to interpret SCCs as grassroots Church of the poor. The emphasis here is on the special role played by all the members without exception. In this Church exist an innate conviction that one cannot do without the other SCC members since they need one another if they have to be witnesses.

Pastoral Constitution on the Church in Modern World (Guadium ET Spes) laid emphasis on the service mission of SCCs. Bishop Kalilombe of Malawi conceived this idea of SCCs based on African traditional clan system [3]. For him, since all Church members have received a call to be baptised in Jesus' name there is no point for the Church to rely solely on the hierarchical office even for simple duties like sharing the word. The lay people could participate in the process of evangelisation assisted by the clergy. It is within this African understanding of traditional roles that many pastors went out strongly to try out the new mission. Bishop of Rulenge Tanzania started using SCCs as a means of transforming the entire Christian family. Bishop Mwoleka of Same Diocese proposed during the 1975 SECAM Assembly in Malawi that SCCs should compose not more than twelve families [4]. For the Church to succeed as a missionary body, the very aspect of being ready to wash others' feet, like Christ did, is indispensable.

In the Redemptoris Missio of Pope John Paul II, SCCs are places where simple people seek to live Christian message to the full in their concrete situation [5]. This is true about what really takes place in the Church. Members seek the word of God within their simplicity of life, obtain healing services in the mission hospitals and probably send children to a Church sponsored school. For them, Christ is present in all these activities. Driven by this zeal, Bishops of AMECEA committed themselves fully to the formation of SCCs in the 7th plenary conference in Zomba, Malawi, in 1979.

In the Instrumentum Laboris that preceded the African synod of 1994, the Bishops of AMECEA reiterated that SCCs were the best model to evangelize the African family. The synod provided an impetus upon which SCCs took shape in different places according to the attitudes of local pastors. Since the inception of SCCs as a pastoral priority in the region, it is time to look into their progress. If SCCs are excellent ways of being Church, what the Catholic Church should do to make them more attractive to all her members was the purpose of this research.

When Pope John Paul II visited Kenya in 1995 to launch Ecclesia in Africa, he reiterated the resolve of the gathering to implement a family Church [6]. He went on to say: "right from the beginning, the synod fathers recognized that the Church as a family couldn't reach her full potential until she is divided into communities." The communities according to this papal teaching should be those that pray and listen to God's word, encourage the members themselves to take up responsibilities, learn to live like Christ and reflect human problems in the light of the Gospel. Borrowing from the primitive Church of the New Testament, the Pope reiterated the collective role that the SCCs can play in handling human challenges such as poverty, hunger, diseases and ignorance.

For the Church to be relevant in terms of what Pope John Paul [6] called reading the signs of the times, its liberating role should rightly begin here. The above exhortation can bring out a clear meaning when read in the perspective of Acts 1:8 "You shall be my witness in Jerusalem..." For this reason, SCCs have served as the cell of 
liberating members from spiritual, material and moral want. Spiritually, members are able to read the word of God, pray, celebrate the Eucharist and raise fellowship. Materially, the members raise funds to assist those in need. It is within perspective that a procedure is designed to determine the level of need. Socially, they guide and counsel one another. In case of bereavement, they console the affected. Whenever some of them are in conflict, an amicable solution is sought from Community level.

In the article, Small Christian Communities, Archbishop Zaccheaus Okoth of Kisumu examined how this pastoral priority can be improved. He raised two concepts that were profoundly important to this study, namely love among Christians and indiscriminate solidarity with all the neighbours [7]. It is worth noting that the Catholic bishops of Kenya recognised the special role-played by the entire nuclear family in the mission of SCCs and the entire Church. This all-inclusive participation extends to other families, which for exceptional reasons may not necessarily be nuclear yet their presence and participation is of great pastoral advantage. They include single parents and old people who may be polygamous. Such families have certain roles in SCCs as set in the Vatican II document. From the Catholic Church's position given above, a Christian establishes a personal relationship with the Community inspired by the following reasons.

\section{Reasons for Establishment of SCCs Sociological Reasons}

Members of SCCs do have a need to be accepted in the face of alienation, brokenness in family and fractured neighbourhood. This might be an obvious reason why SCCs attracts some members and not others. There is a resultant pressure from insufficient conditions of life whether spiritual, social, health, environmental and cultural that needs response [8]. Members of the neighbourhood begin to realize their own power to change their living conditions and, therefore, begin to assign themselves ministries that are aimed at assisting themselves.

As mentioned before, in the early Church, such ministries as service to the sick, orphans and widows were intended to bring a sign of hope to the disabled, abandoned and emotionally depressed. Little has been done to make SCCs vibrant while executing such simple yet noble duties. If properly managed, SCCs can be very instrumental in the development of the Community morally, spiritually or materially.

The purpose of this study was to propose a strategy for improving SCCs. Through these cell group members have organised themselves to raise other members for baptisms or even marriage instructions. Members have used the group to develop income-generating projects such as zero grazing and those without capital have been assisted to realise their aspirations. Through Church projects members within the society have been able to connect the spiritual as well as material wealth to assist the poor.

\section{Spiritual Reasons}

Members of SCCs reflect upon scriptures and work towards deeper appreciation of God's word. It is here that they find it easier to pray and share with others. Generally, SCCs are characterized by a sense of belonging and mutual support. Like in the Acts of the Apostles where the twelve disciples were daily engaged in sharing the word of God, SCCs provide forums for fellowship [8]. The sharing of the word of God does not only end with the meeting. They also go out to put into practise. The procedure for sharing the word is such that after scripture is read, members reflect upon it and share the task of the week. This part of the action is so crucial because it entails being concerned for others. They do this in order to grow spiritually and inspire others towards goodness.

\section{Ecclesiastical Reasons}

Ecclesia as a term refers to a body of believers who together profess one faith in the death and resurrection of Christ [9]. The New Testament calls such a believing Community the Church. The Catholic bishops in the AMECEA region opted for SCCs as a way of encouraging participation of the lay people in the ministry of the Church. Furthermore, they had this as an option through which self-reliance could be realized. SCCs as agents of evangelization provide forums through which members of SCCs contribute pastorally, socially and financially in order to make up for decreasing donor support from abroad. At times, this burden turns out to be too much on some members and may make them unwilling to attend meetings. Therefore, all the members should participate in sharing the burden.

While maintaining that the above are reasons Christians form SCCs, it is prudent to admit that the Catholic Church in Eldoret, and Kapcherop in particular, is quite far from meeting the objectives set by the AMECEA Bishops. Persistent absence of men clearly indicates that a lot of pastoral education needs to be done. A closer look at the functions of these communities brought out the challenges that members face as they participate. Finances are so limited yet the requirements and activities planned by the Christian Communities are so many. This slows down the expectations of the members while scaring others all the same. On the other, the question of insufficient pastoral education drains members away from an otherwise serious commitment. While the members expect that leaders should be polished in 
their management skills, some of the pitfalls that members of SCC experience dampen their commitments. Most of these challenges that face SCCs had a special place in the Synod of African Bishops held in Rome.

\section{African Synod on Small Christian Communities}

The Synod of African Bishops that met in Rome in October 2009 profoundly accorded SCCs a special attention terming them as grass root Church. For them, the Church as a family cannot reach her full potential unless SCCs foster close human relation. As indicated in the Vatican II Council document, these SCCs are schools of solidarity. The African Bishop thus emphasized that: "The Christian family is the cell of the living ecclesial Community; it is also the fundamental cell of society" [6]. In this case, the Church fathers reiterated that the SCCs, just as some families do, should be characterized by sharing and responsibility. The objective of this study was to highlight those key elements that can make SCCs attractive to the members, particularly men. The African Synod indicated an element in an Africa family where joy trials and difficulties were shared in a trusting dialogue.

It should be noted here that SCCs, as they are today, face challenges ranging from leadership, membership and so forth. Responsibilities that cause conflicts at times need to be solved in line with specific and accepted traditional African codes. The African synod emphasized the need to recover and promote the precious values of traditional African family.

Cardinal Hyacinth Thiandoum clearly stated: "The concept of family, which is strong in African expresses in concrete imagery, the profound ecclesiological idea of the communion of believers, a fellowship of diversities of rules and persons" [6]. SCCs are places where the faithful can communicate the word of God and expresses it in service and love to one another. SCCs are seen as true expressions of ecclesial communion and centres of evangelization in communion with their pastors and are a means of evangelization. The SCCs have a beneficial influence for the active participation and initiative of lay people in the life of the African Church. They make the Church really present in a given place and make people feel they belong to and are responsible for the Church. The Synod Fathers saw the SCCs as means for the Church in Africa to be able to support her in all spheres.

Thus: "It is necessary for each Christian Community to be organized in such a way that it is able to provide for its own needs as far as possible. Beside qualified personnel, evangelization requires material and financial means which they often lack them" [6]. Though the Synod Fathers underlined the advantages of SCCs as a way of being Church, they did not overlook the difficulties and problems that sometimes bedevil them. According to the African Bishops, irregular or at times lack of participation of men in the SCCs was seen as something traditional. "Small Christian communities have not been experienced as a solution for all problems, but have nevertheless made an enormous contribution to the vitality of the Church and especially to the responsible participation of lay people" [10]. This indeed was the purpose of this research, namely to look into ways through which SCCs could be improved to make them attractive to members.

\section{Small Christian Communities in Eldoret Diocese}

Benjamin Kiriswa reiterates the Diocesan pastoral plan adopted in 1981. The pastoral planning committee was solely responsible for its inception and realization. The Diocese of Eldoret took it upon itself the role of training leaders known as resource teams for a start. They included catechists, pastoral council leaders, priests, religious groups and other interested parties. The induction courses went on in several places through workshops, seminars and visitations to various parishes.

A programme known as Diocese of Eldoret Leaders and Trainers Assembly (DELTA) was initiated to create awareness of this new vision of the Catholic Church [11]. The main vision was to lead members into a living relationship with Christ through SCCs. Secondly, the Catholic membership had to be brought to the new understanding of neopastoral realities and challenges tabled in past meetings by the AMECEA Bishops. The following were the objectives of the SCCs in the Diocese of Eldoret:

- To draw members towards self-reliance in line with new pastoral realities after 1980 characterised by Structural Adjustment Programmes (SAPs).

- To develop a Community (Koinonia) spirit where responsibility and sharing were key ideas. This is so challenging in the contemporary society.

- To share talents, gifts and endowments as a group.

- To involve everyone in parish pastoral life while remaining true to the entire Church leadership (Diocesan archives no. DE76).

From the onset, this Catholic Diocese saw SCCs as a way of renewing the lost sense of being Church. In order to do this, SCCs were meant to help members to understand their faith, study the Bible and share its contents if possible. Bishop John Njenga, the then Catholic Bishop of Eldoret, appealed to priests to introduce SCCs in all parishes as a priority in the early 1980. Initially, Bible sharing after prayer sessions characterized the SCCs. Through SCC training and 
focused leadership, members soon began to comprehend what these SCCs entailed. Matunda parish was chosen for pilot scheme. It was here that Catholics felt the need to implement creative ways of spicing up their faith. The neighbouring protestant Churches in Kakamega's St. Mark were so vibrant and so involved in Church functions that they challenged their counterparts in Matunda. For them, mass was not enough to serve the needs that members had. The years that followed 1980 for the Catholic Diocese of Eldoret became a defining moment characterized by the need to depart from dependency and move into self-reliance [12]. Reliance here encompasses all aspects spiritual, pastoral, economic, political and financial. This demanded that all members were to be involved without exception. There was also need to rely upon one another in matters of faith.

According to Kiriswa [11], then the parish priest of Matunda, there was an urgent need from among the Catholics to give an account of the faith they so hold dear. Questions such as resurrection of our Lord and Sunday worship were so crucial that any formation process in SCCs needed a serious consideration. Formation of SCCs in Matunda parish was also meant to respond to marriage preparation, catechumenate and baptism. The poor people in the Church had numerous problems that demanded the Church to respond promptly if it had to reflect the conscience it is known to have. With such challenges, it was insufficient to meet on Sunday for prayer and mass. The Diocese organised DELTA course in Ggaba Pastoral Institute to prepare leaders for challenges towards 1980 and beyond.

The Diocese also made an effort to be represented in almost all the plenary meetings where SCCs were discussed. From this study, it was gathered that little was discussed in terms of how these SCCs reinforced spiritual and leadership roles of the members in the Church. When members who used to be active suddenly shifted to be indifferent, some questions were then raised: on the objectives and goals of SCCs in the AMECEA region. During the formative stages of these SCCs in Eldoret, there were items that may have been ignored this could affect participation of members. All members could be understood in this context to mean the whole family where parents and children were part.

If the Diocesan pastoral plan was responding to the weakening pastoral spirit, one wonders whether any research was carried out to determine priorities and limitation of this new Pastoral option in terms of participation of members. Despite the perception that SCCs would bring forth many solutions to Pastoral challenges in Eldoret Diocese, little may have so far been realized. A closer study should be conducted into traditional forms of leadership ignored in the formative period. The Diocesan pastoral plan borrowed the idea of making the Church self-reliant, self-governing and self- propagating [13]. The plight of the poor, the widow, the hungry and thirsty was supposed to characterize the Church's concerns.

While all these changes were accommodated, the pastoral team published Jumuiya Ndogo Ndogo to remind all Catholics to be a praying Community [13]. The content of this pamphlet reflected meaning and purpose of SCCs in the entire Church of Eldoret. Great emphasis during these formative stages was the service nature of the SCCs. Diaconia (the service role of the Church) planned ways to support those in need, as well as showing solidarity to them. Nothing had been of much concern regarding membership and participation. The assumption may have been that people would easily embrace one another.

When SCCs were first conceived, they were thought to be sessions for bible study, liturgical preparation, prayer and visitations [14]. Preparation for liturgy ranged from cleaning the Church to preparing and presenting offerings to meet the needs of the priest among others. Then, if the role of SCCs is only limited to preparation for mass as is the case of most the Churches in Tenden, this may turn out to be so limited. Many critics of this pastoral option have also seen SCCs as micro financial sourcing units of the Church's macro self-reliance projects. The contributions required of all members of the SCCs scare some of them away. This calls for a study to evaluate the impact of self-reliance programmes on SCCs life.

The use of the word of God in SCCs points to the centrality, that scripture has in their meetings [14]. Not all members of the SCCs are able to read or make use of scripture as Bishops and priests expected. SCC leadership is open to men and women. The evangelisation movement targeted areas not reached by clergy. Men and women carried out preaching, healing, leadership and family apostolate.

Unlike in the Acts of the Apostles, the work of preaching in the Church belongs to the ordained ministers most of whom are men. Emphasis in SCC meetings is on sharing God's word and relating to members' life situation. In a nuclear family set up, men played a central role mostly in leading family prayer. It was intended in this research that reasons for reluctance on the part of men to attend SCCs be brought forward. Even with such limitations as level of literacy, lack of resources and time, the word of God assisted members to read and meditate upon the word before committing it to prayer. Inspired by the words of scripture, Catholic priests in Eldoret resolved thus: 
We are convinced that God who speaks to us through scripture is the same God who is continually speaking to his people through signs of time, the events the situations and conditions of man's life in our day. We take these signs of our times in our country as the challenges of God for his Church in the coming years [15].

The pastoral option of SCCs in Eldoret emphasised family apostolate. The Pastoral Councils in the Diocese began by encouraging members to attend prayers in their homes. The leaders requested families to buy Bibles and hymnals to help them back at home during family prayer sessions. The leader of the meeting would take the Bible and introduce the lesson of the day followed by a reading and meditation. Another reading would follow a sharing to identify how the reading could be relevant. Actions are then sought and all members get a chance to say something. Such prayer meetings were held once a week. In the end was a prayer mentioned in spontaneity followed by a relevant hymn to close the meeting. The Community would occasionally identify whether there was an action that required their attention. This ranged from making a visitation to the sick, planning for a function or even a small fundraiser.

By these gifts, God makes members fit and ready to undertake various tasks and offers for renewal and building of the Church [16] Members in these communities of Matunda remained concerned towards one another. St. Paul challenges members of the Church in Corinth to extend the spirit of concern so that, whenever one of them suffered, the rest were affected; whenever there was joy the rest also partook in it ( 1 Corinthians 12:25). This Pauline understanding of communion with the suffering neighbour can rightfully be understood from the pastoral option taken by deanery of Marakwet. Men were vested with leadership role and were the overseers in the Community. The challenge of cattle rustling in the region and the mistrust created by such practise calls for a deeper reflection on the mission of the SCCs as cell of the Church. The reality of post-election chaos in the history of the Kenyan Church challenges it to re-think on Christian solidarity that should begin from SCCs.

\section{SCCs in Marakwet Deanary}

Fr. Benjamin Kiriswa examined the pastoral option of SCCs in what the resource team called Maisha ya jamii Ndogo Ndogo za Kikristu. The work pointed out that through these SCCs the Church particularly in Eldoret Catholic Diocese would grow towards making human relationship a springboard by which all members can be drawn closer to the Church. Herein, the Catholic Church attempts to solve pastoral problems within their own context. In Kapcherop parish, for example, it may be insufficient to conclude that only the Marakwets form a larger majority of the SCC members. The use of this term in the study implied the current administrative location of the parish. The spirit of extended family is very strong in the Marakwet culture. Some of the members are migrant farmers who have homes in lower Marakwet regions of Arror, Chesongoch and Nerkwo.

Marakwet Administrative units (Kokwotinewek or villages) are sizeable enough to form SCCs. This supported Elochukwu Uzukwu's in his book A Listening Church [17]. Elochukwu, posits that such a Community be characterized by not more than fifty members on average. A catechist from Kibigos Sub-Parish understands SCCs not just a means of evangelisation but also of human promotion of those disadvantaged in the Marakwet society (Response to an oral interview with Kangogo of Kibigos in Kapcherop). The mission of the Church becomes so clear right from the concern they show for one another. The then Bishop of the Diocese of Eldoret, Kenya, the late Cornelius Korir, in the seminar paper Lay Faithful, emphasised that such SCCs fostered responsibility among all Christians and hence made them aware of needs around them [15]. This was a vital contribution to the central thought of this study that all the members should assume their indispensable role of SCCs in Kapcherop as agents of evangelization. The implication of this call was that men who at times fail to be part of SCCs should be encouraged to take their active part as leaders the same way women do.

Bishop Korir, while commenting on proclamation in the Instrumentum Laboris No. 24 that preceded the 1994 African Synod in Rome, pointed out strongly that lay ministries manifest their role not because of shortage of priests but because the whole Church is ministerial [15]. Even with the above tremendous roles that awaited all the SCC members, Kapcherop Parish had always faced pastoral challenges related to participation of members in SCCs. Since its inception more than twenty years ago, the Catholic Church in there had been challenged by an upsurge of evangelical ministries where women receive affirmation and means to cope with stress of the extended family structure. What this means for SCCs today is that there is need to strengthen guiding and counselling programmes that targets the family institution. This will eventually make the members get affirmation from others in the Community. The pastoral challenges related to participation of the SCC members were not solely limited to Kapcherop but also in other Sub-deaneries within Marakwet.

\section{Small Christian Communities in Sub-Deaneries}

The Catholic Diocese of Eldoret's Pastoral Planning Committee was responsible for the birth of SCCs. All parishes and sub-deaneries had to draft their work plan out of this committee's work plan. Though nobody has written about participation of SCCs members in the Diocese, minutes and other records in the diocesan office suggest that; these 
communities aimed at bringing together people of the same age and similar customs such as the married youth and professionals (Diocesan archives No. DE37).

The characteristics raised by Rodrigo Mejia fitted the description of SCCs in Kapsowar, Chesongoch, Arror and Kapcherop Sub-deaneries as: "Groups of people with one aim such as fighting for justice, helping the poor or working for the development of people. They get together to listen and meditate on God's word, celebrate sacraments especially the Eucharist" [16]. Members attempt to internalise God's word and challenge one another to assist those in need. The responsibility to do this rests with all the members. Even though this may be the ideal, some do not find it as an obligation. Initially, it was projected that this spirit of concern among members would easily be picked by all. There was an assumption that SCCs would easily turn out to be an extended family of God.

Oliver Olozie underscored the indivisible nature of the body of Christ in which all believers were members [18]. Olozie developed the central argument of an all-inclusive Community where one felt obliged to participate. Within them was a focal point where Community life was given a meaning. These Sub-deaneries have turned out to be an extended family of Christians who practice and celebrate togetherness occasionally. Apart from this, leaders identify the needs of the Community members particularly those who need assistance. Here, lay ministries were established to respond to the local needs. When such ministries as catechism, development, health, finance, justice and peace were first conceived, members responded very well. They rose up to the new Challenge except for minor cases where the impetus started waning away so fast. The strength associated with SCCs had made all the Sub-deaneries see themselves in the light of what Margaret Hebblethwaite called a new way of being Church [19]. In all the communities, only a small number of men or at times none would attend.

Oliver Olozie argued that in an African family, the responsibility of the father must be complemented by the task, the role and responsibility of the mother [18]. This pointed out a great challenge that faces SCCs in these subdeaneries such as sharing, full participation of all, absolute equality of persons and outreach to others. This becomes even critical when some of the members ignore their duties making others carry their burdens.

\section{Statement of the Problem}

Much has been written concerning SCCs in the Catholic Church. There are others not mentioned above and yet they have not adequately covered aspects relevant to this study. The area that has received little attention is that of participation in SCCs. A study done by Bernard Ugeux in Zaire in 1980 shows that in SCCs the attendance and participation of women far outweigh that of men [4]. The Catholic Church teaches that the Church should reflect a family set up whereby both parents (if possible) together with their children attend SCC meeting. What Ugeux presents is an undesirable situation that needs to be addressed. In order for the Church to maintain the ecclesiology of communion based on the family where children, men and women are part, ways should be sought to make SCCs relevant and attractive to all members. SCCs will not mirror an African family if the tasks and responsibilities of the mother do not compliment the task and responsibilities of the father. SCCs have been reduced to a gathering of women and children.

The problem in Tenden Sub-Parish is on how to involve men in Church life beginning from SCCs. This is because they have an indispensable role to contribute whether financially, socially or morally to the Church ministry of catechism, healing, evangelising, Christian matrimony, justice and peace, helping the poor, Eucharist and leadership. All these demands all members to be actively present. Although there has been much effort and emphasis on full participation in SCCs by all Catholics it's apparent from previous researchers and experiences that participation by male Catholics in SCCs is poor or wanting. Previous researches have not addressed comprehensively the factors that affect male participation in SCCs activities. It is for this reason that this study sought to address these problems and suggest possible solutions for it.

\section{Materials ANd Methods}

The research was descriptive, and used structural functional approach to bring out the meaning and function of SCCs to a new reader who wishes to know or join. The structure and functions of these small units are highlighted in order to appreciate how one aspect leads to the other. Branislaw, in his Structural Functional theory, emphasises the preeminence of the social world over its parts. This theory was used to indicate that the parts play a crucial part in making the whole. This means that for the Church to function effectively, SCCs should be strengthened.

A sample population of 132 was used in line with the table provided by Krejcie and Morgan [20]. In order to obtain the information adequately the sampled population was divided into five strata representing levels of leadership in these Small Christian Communities. Purposive and stratified sampling was used within the strata to identify 12 key informants from among Church leaders deemed to have had information required for this research. These key informants were priests, Deacons, Seminarians, and SCC leaders. 
The study employed questionnaires and interviews to solicit qualitative data and not quantitative. Primary data came from oral interviews and responses to the questionnaires from the sampled population. Secondary data was generated from libraries in Catholic University of Eastern Africa (Gaba Campus Library), Mitume Centre, St. Mathias Mulumba Seminary in Kapsabet, St. Thomas Aquinas Seminary-Nairobi, Margaret Thatcher Library and Diocesan archives. After data was collected it was then analysed using descriptive statistics.

\section{RESUlTS AND DiSCUSSION}

\section{Factors Influencing Participation of Men in SCCs}

The researcher sought to establish the factors which affect the participation of men in SCCs activities so as to endeavor to enhance their participation. It came out that $15 \%$ identified pre-occupation with work, $35 \%$ home responsibilities $10 \%$ the expected returns/ reward, $25 \%$ family environment and $10 \%$ the SCC leadership. This is shown in Figure 1 below.

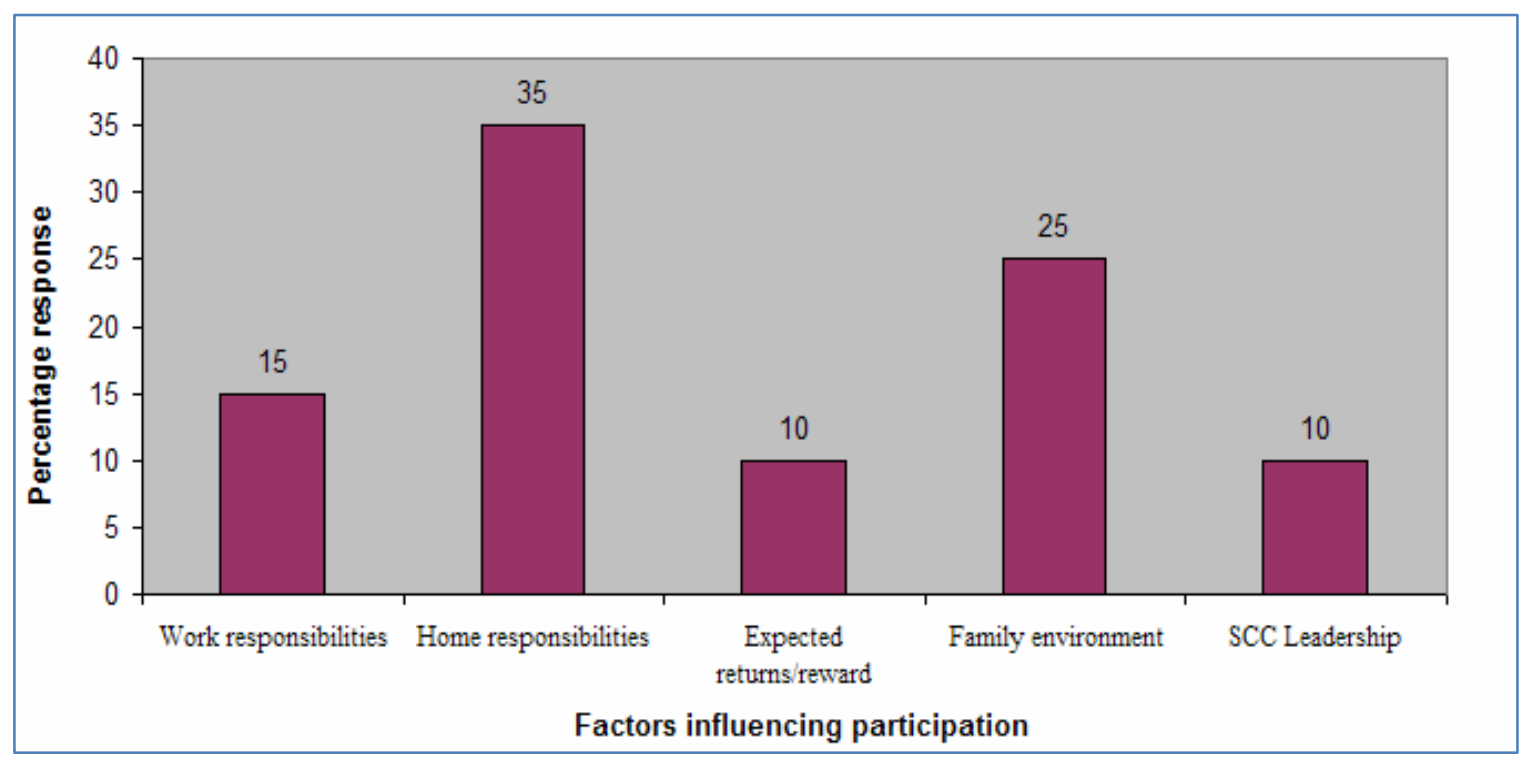

Fig-1: Factors influencing participation of men in SCCs

This means clearly that whereas men blame social responsibilities for the laxity in SCCs, there are many other reasons that make them either shun meetings or delegate to their wives if married. There is an indication from the study that men seem too committed to their own chores other than being involving in Church activities. It was hypothesized in chapter one that social responsibilities are mainly to blame for continuous absence of men in SCCs. SCCs in Tenden Sub-Parish of Kapcherop are made of extended families and mostly members from the Catholic faith. In the study, this is a strong factor that contributes to persistent absenteeism on the part of men. There are other reasons such as economic, cultural or otherwise that make them deliberately avoid SCCs or do so decisively. Culturally, the Marakwet culture does forbid a married man or otherwise to sit with in-laws.

On whether leadership of SCCs is a possible factor for laxity on the part of men, in Tenden members gets opportunity to elect people to various positions. At times, there are appointments made by the priest to perform various duties. There was a stronger pointer towards members preferring to choose their own leaders and the implication here is that this may not be a significant reason for the failure of men to participate. However, there is a possibility that there could be a cultural influence indicated earlier. Men in Tenden are very relaxed particularly when led by others other than themselves.

\section{Level of Education of Catechists}

It was necessary to seek this information to establish the level of training of catechists. From the findings that $70 \%$ reached primary level and 30\% secondary level. This is shown in Figure 2 below. 


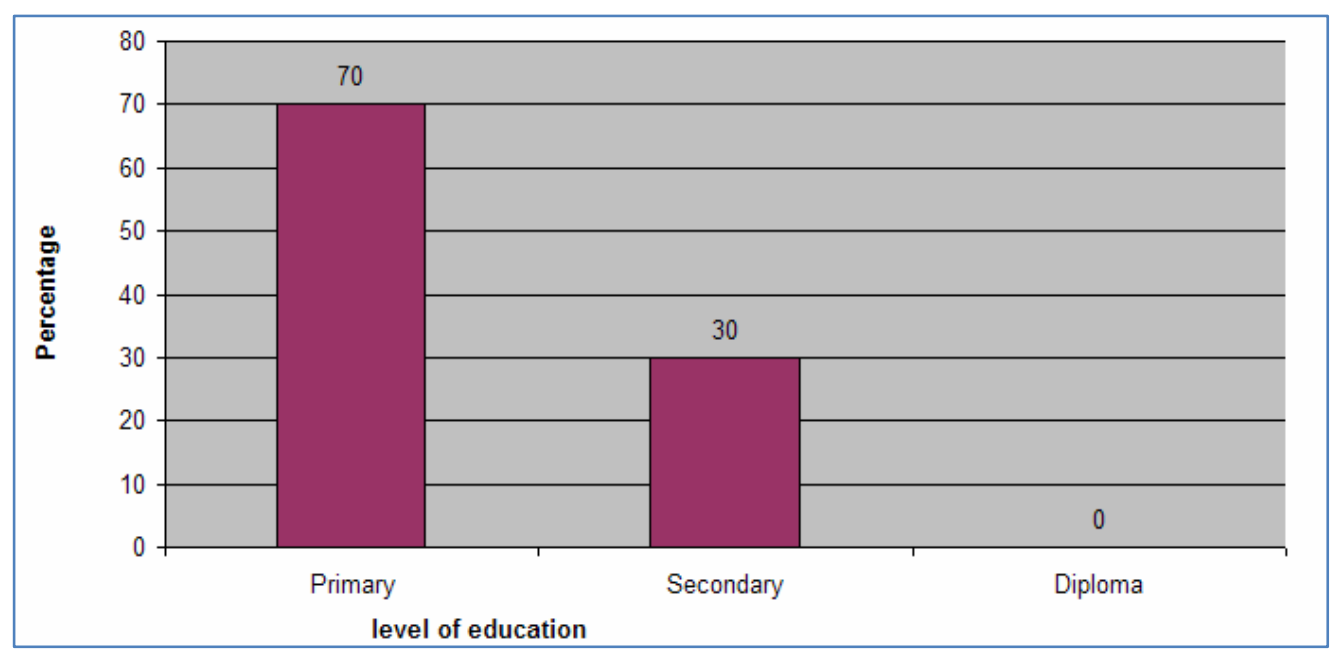

Fig-2: Level of education of catechists

From the priests and catechists who were key informants in the interview together with SCC office bearers it was found that only three catechists had attended catechetical course in Mitume centre Kitale. Others had gone through in-service course at St. John the Baptist pastoral centre which is also a form of training. Of the catechists, $70 \%$ were untrained meaning that their level of comprehending contemporary pastoral challenges is limited. Members at times responded that they find it difficult to correct a catechist who is not educated. They would rather avoid meetings than be instructed by leaders whose level of organisation and planning is wanting. As indicated in Figure 2, most members of SCC are better educated than the catechists and the leaders and this poses some pastoral challenges. An example of this challenge could be the interpretation of scripture. At times catechists who may not have been exposed to modern trends in theological thought would fear communicating or sharing God's message in the presence of members of SCC who may have handled a similar content at some level.

The parish council remained non-committal in giving reasons for not training all catechists. They argued that being a catechist is a call and it is hard at times to get one who is educated accepting to serve as a catechist. The priests' response on the training of catechists indicated that from many invitations made for young people to come forward as catechists; hardly do they get any responses. From the observations, those who accept to serve as catechist do so as volunteers and not as a call. A closer study needs to be carried out to determine whether improved pay for the catechists would induce the educated members to avail themselves in this noble service.

\section{Training of Catechists}

The research sought to establish if the catechists in the Sub Parish of Tenden are trained. This enabled the researcher to ascertain their leadership qualities, knowledge and level of psychological understanding. It was established that $30 \%$ were trained and $70 \%$ were not. This is shown in Figure 3 below.

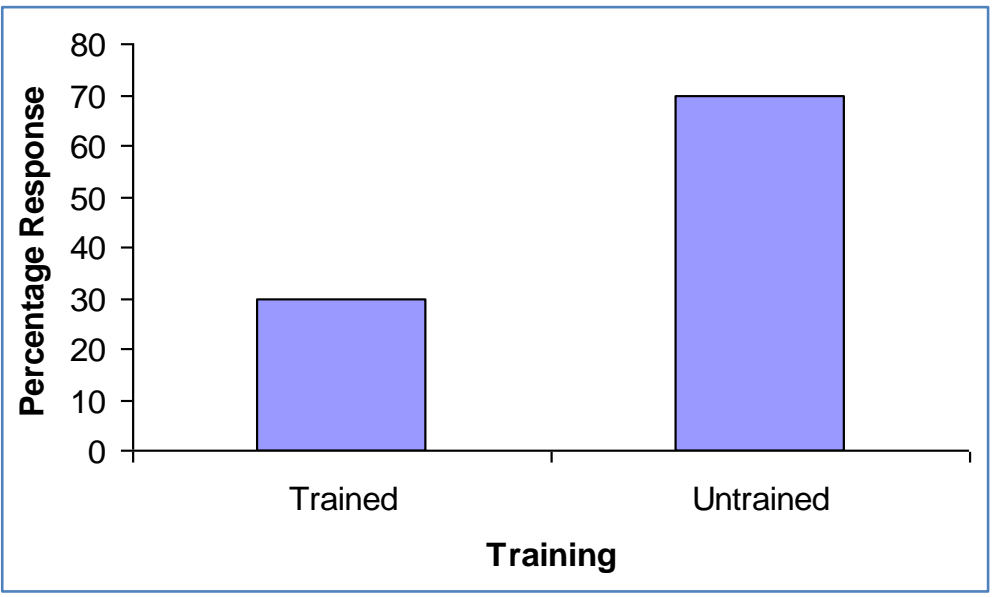

Fig-3: Training of catechists

The catechists conceded that the highest level of education that they reached was primary school except few who had gone through secondary school level. What this meant was that there exists a disparity in the education level between SCC members and catechists. At times members do not find anything challenging from an untrained catechist. 
On the other hand, it came out from the priests interviewed that catechists shun in-service courses due to their educational background. This was noted as a reason why most of the men loath attending SCCs.

This study identified that education is closely related to focus leadership. Most of the respondents suggested that they would rather carry on with their own businesses rather than listen to uneducated catechists. Most of the catechists have moderate education and therefore limited skill of organizing and co-ordinating pastoral activities. Despite the fact that the level of education of the members of SCCs is generally low in the Sub-Parish, most of them expect catechists to be in command of what they teach and believe.

\section{Attendance of In-service Courses on Pastoral Strategies}

The research sought to establish whether the catechists had attended in-service seminars on pastoral strategies. The researcher attempted to establish if they are trained on the dynamics of Christian behavior and practices. Although $90 \%$ were in agreement that they were untrained, they saw the need for in services courses. However, $10 \%$ responded that even if they were given time to learn, they would not. This is shown in Figure 4 below.

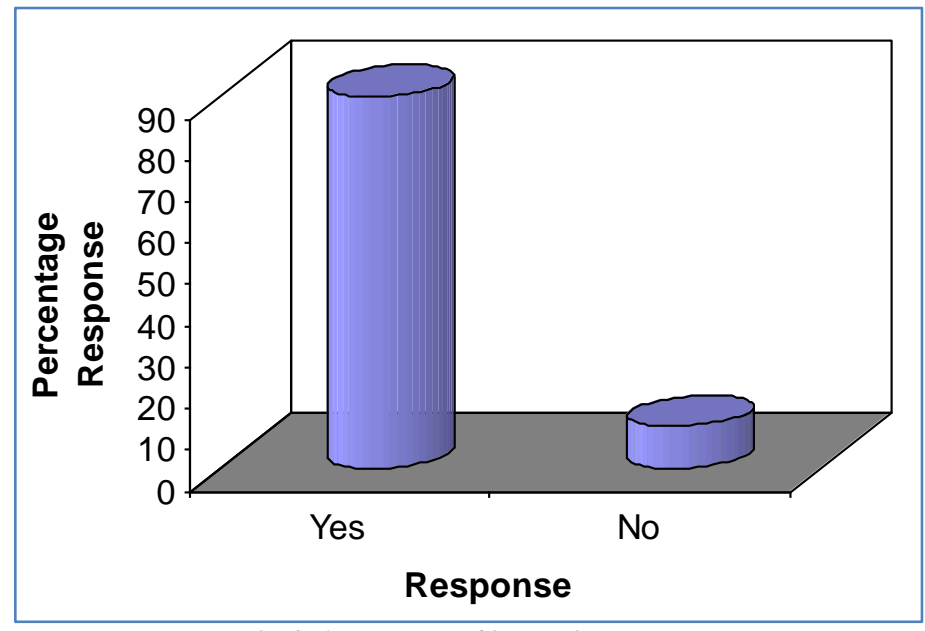

Fig-4: Attendance of in-service

According to most of the parish leaders, the parish had enough pastoral literature and facilities. The challenge that recurred is that catechists who should educate and co-ordinate pastoral work required training. The researcher found out that most of the pastoral workers, catechists included relied so much on priests even while dealing with simple issues of co-ordination. There was an apparent disconnection in dealing with SCCs between catechist and member according to the respondents.

\section{Facilities available at the parish}

The research sought to establish the amount of facilities available at the parish to ascertain how they assist the pastoral activities. From the respondents, New Catechism of the Catholic Church, Pastoral guides, seminar materials, and Bible illustration charts, seed magazines, Lenten pull-outs and Bibles were identified as inadequate. This implied that the parish does not have all the facilities required for pastoral activities and therefore members cannot participate fully in bible study, preparation for sacraments, prayer meetings and home visitation. The co-ordinated efforts of the parish council, priests and pastoral workers make the activities of SCCs go on well despite the shortage. From the items gathered in the interview, liturgical preparation overrides seminar and preparation before the sacraments.

\section{Adequacy of the facilities}

The study sought the views of SCC officials on the adequacy of the facilities in enhancing pastoral activities. The findings indicated that $85 \%$ said they are enough while $15 \%$ said they are not enough. This is shown in Figure 5 below. 


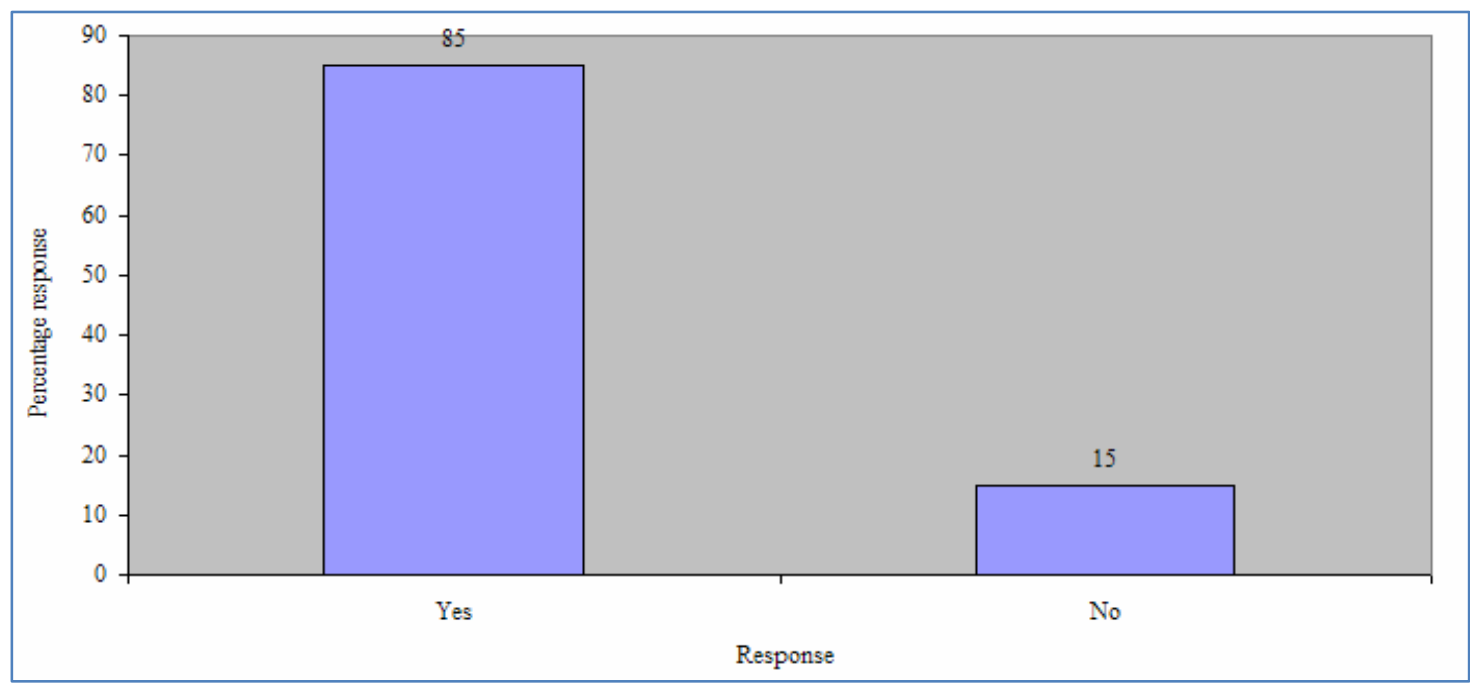

Fig-5: Adequacy of facilities

\section{Members' View on SCCs}

The research sought to find out the opinion of individual members on the SCCs so as to establish if they were relevant. It was established that $80 \%$ said they liked it and 20\% said they did not like it. This is shown is Figure 6 below. Members liked SCCs and, therefore, would want them to continue existing. When asked further to state reasons for their view, most of them said that it had changed their social-religious, political and economic status. Growth and development of SCCs in Kapcherop parish particularly was due to a tremendous support given by the parish priest, Deacons and the Pastoral councillors. Members cited their level of satisfaction especially from the number of pastoral activities conducted in these SCCs. Despite the massive support of the pastoral team the challenge of few men who turn out for Community pastoral activities remained.

\section{Position in the SCC}

The research sought to establish the position of members to ascertain their leadership structure and their roles. The existing position included members, vice chairperson, chairperson, treasurer, youth representative, vice secretary, secretary, organizing secretary and self-reliance co-coordinator. It was interesting to note that these offices encompassed nearly all the aspects expected to be addressed in the SCCs. This shows that the group is organized in the structure of non-profit making organization. The projects that members involve themselves in include animal husbandry, chicken and poultry farming among others.

The priests and deacons are at the forefront in the activities of the SCCs in most cases those who are in position do so having been proposed by priests and deacons. From this study, it was noted that the position of priests and deacons enabled the parish to work smoothly. In the presence of such diversity, members have a better chance of exercising their roles as required. The implication of such a structure is that whatever activity goes on in the parish gets down to the members. Another question was asked on whether socio-cultural and economic factors were to blame for the cause of the absence of men in SCCs.

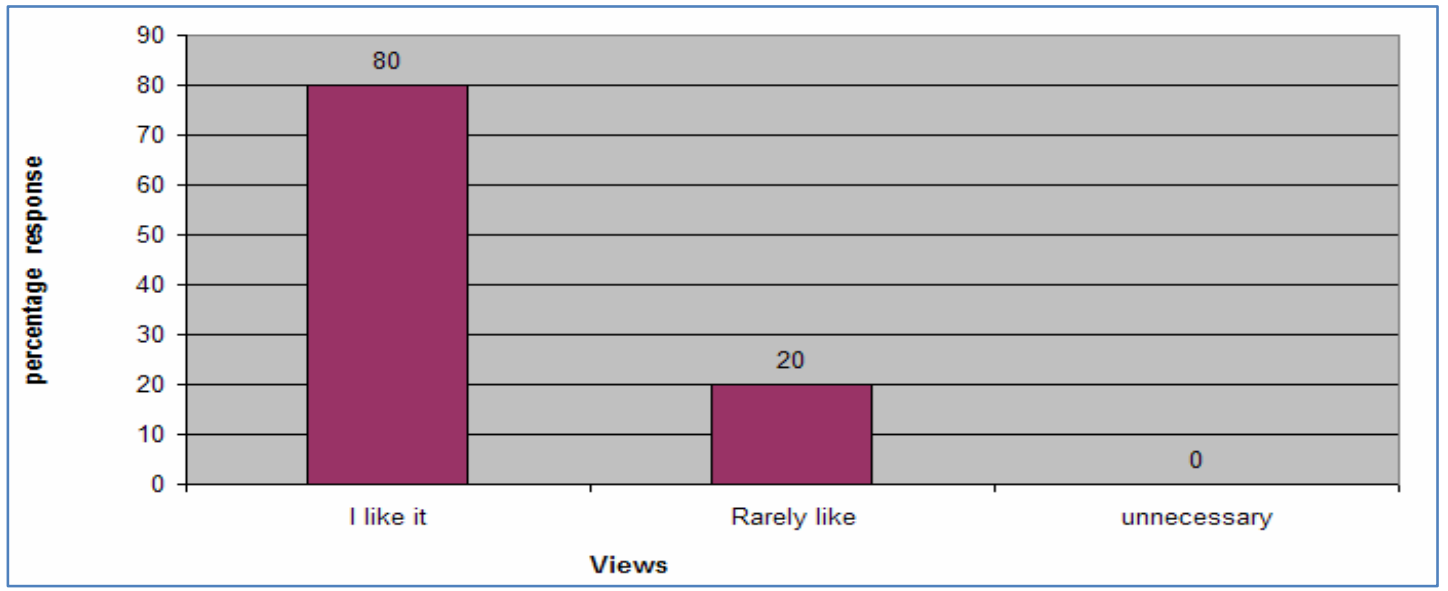

Fig-6: Members' views on SCCs 


\section{Men's Experiences while in Small Christian Communities Activities}

It was established from the study that men face the following social cultural economic challenges while taking up leadership roles:

\section{Cultural beliefs of male dominance in community activities and decisions}

From the data gathered, men in the SCCs had interest in leadership positions if given chance. This does not mean that they have been denied. The reality was that in a case where women form a majority in attendance, men though willing to lead are disillusioned by their inadequate representation in the meetings. However, there were notable examples of St. Monica in Chepkaway where several respondents reported that they were barred from exercising any official and active liturgical functions until they officially wed according to the requirement by the Church's Canon law. At times, those members who felt that they have been deprived position of leadership in favour of women or young people keep off the function of the SCCs. This has greatly hampered development both spiritually and materially.

\section{Conflict between Pastoral guidelines and cultural beliefs system}

Several respondents who were orally interviewed explained that though SCCs were avenues for members to express what they feel about their Christian faith, there existed a disconnect with Marakwet customs and belief system. A good example is that of members who though polygamous desired to take up leadership roles in these Communities. Ecclesiastical norms bar such members from taking up these leadership roles in SCCs except where pastoral reasons demand that such a rule should be relaxed. Though this requirement is pastoral in nature the implication is so strongly implied in Canon 226 thus: "Those who are married ....in accordance with their own vocation, to strive for the building up of the people of God through their marriage and family" [21].

One other aspect that strongly shapes the Marakwet family unit is that of communal curse. Some of the members of the SCCs even to date belief on the power that lies behind these communal curses. There are those who though belong to this community want to be associated with the urbane population. This group does not associate with the traditional beliefs related to curses. These two groups, according to the study, clash in cases where some members are known to be engaged in community cursing ceremonies. The reason given for the impact it has had on male participation is that in most of these ceremonies men are actively involved. There were customs related to kendiisio (wife inheritance). When the family appoints a member of the SCC to traditionally assume the roles of the deceased, some other members of the Community translate this as an intrusion into ones' family. This in most cases creates tension and bad blood in the SCCs.

\section{Inadequate finances and male preoccupation in work places}

While this was noted by many respondents as a reason for absence, several SCCs that meet on Sunday a day understood to be a time to rest still reported absence of men. In Tenden Sub-Parish, women are engaged in small enterprises such as food kiosks to support the family. The study found that in most cases women provide a greater support than men, though the role of men in this case would be remote. This still portrays men as members of the community acting at the periphery. Another study needs to be carried out on whether there exist a certain lifestyle that brings about fear of association between the male and female counterparts in SCCs.

\section{Inherent human behaviours that make men to separate from women groups}

One respondent from St. Peter's Kaptiony who was interviewed asked pertinent questions concerning some members of the SCCs who were either single mothers or widows. This group according to the research engaged married men or even the young people in extra-marital relationship and risked destroying SCCs. In this category too were some men who though old enough to receive holy matrimony as required by the Catholic Church, kept on co-habiting with some members in the SCC. What this implies for the research is that some members, who fear straight confrontation of such relationships, would rather stay away. It was necessary at this point to look at some of the factors that constantly hindered men from attending these Small Christian Communities.

\section{Factors that Lead to Undesirable Situations in SCCs}

The research sought to establish the situations or factors, which have made it difficult for men to participate in SCCs. It was established that 50\% strongly agreed that SCCs are financially demanding, $40 \%$ agreed and $10 \%$ disagreed. Moreover, $60 \%$ strongly agreed that their culture did not allow men and women to interact freely, and 40\% agreed. Ten (10) percent strongly agreed that SCCs rarely addressed current problems in the Community like poverty; 20\% agreed, $40 \%$ strongly disagreed and $30 \%$ disagreed.

On polygamy, being one of the major hindrances, $20 \%$ agreed while $30 \%$ disagreed and $50 \%$ strongly disagreed. Additionally, $70 \%$ strongly agreed that the traditional roles of men in SCCs have been overtaken by women, $20 \%$ disagreed and $10 \%$ strongly disagreed. These roles include the parental duty of guiding and counselling. Most of these 
challenges facing the institution of the family are discussed in SCCs. Sixty (60) percent agreed that professional commitments because absenteeism 30\% strongly agreed 10\% disagreed. This is shown in Table 1 below.

Table-1: Factors that Lead to Undesirable Situation in SCCs

\begin{tabular}{|c|c|c|c|c|c|}
\hline Factors & SA & A & SD & $\mathrm{D}$ & $\mathrm{N}$ \\
\hline Percentage (\%) & $\%$ & $\%$ & $\%$ & $\%$ & $\%$ \\
\hline SCCs and financial demanding sessions & 50 & 40 & - & 10 & - \\
\hline There is a lot of backbiting in SCCs & & 20 & 40 & 40 & - \\
\hline Our culture does not allow men and women to intermingle freely & 60 & 40 & - & - & - \\
\hline SCCs rarely address current problems in our Community such like poverty & 10 & 20 & 40 & 30 & - \\
\hline Polygamy is a major hindrance to participation in SCC & - & 20 & 50 & 30 & - \\
\hline The time which meetings take place is okay & 30 & 50 & - & 20 & - \\
\hline Those unemployed fail to attend meetings & 60 & 20 & 20 & - & - \\
\hline Professional and social commitment cause absenteeism & 30 & 60 & - & 10 & - \\
\hline I prefer to do my own business than attend meetings & 40 & 30 & 20 & - & - \\
\hline SCCs undermines traditional status of men & 70 & - & 10 & 20 & - \\
\hline Members need to avoid meals in SCCs meetings & - & 10 & 20 & 40 & 30 \\
\hline It is okay for women to lead SCCs activities. & 20 & 60 & 30 & - & - \\
\hline
\end{tabular}

Source: Field Data

As the case above presents itself the financial demands, time and professional commitments are the main situational factors leading to undesirable situation in SCCs.

\section{CONCLUSION AND RECOMMENDATIONS}

Throughout this discussion, SCCs in the Catholic Church depict a pastoral attempt to live up to the apostolic calling of love, charity, care, concern and faith. The Church today faces difficulties related to formation and management of SCCs. Most of these challenges came out from the respondents. Generally, there is low male participation in SCCs. The main reason given for low male participation was the perception that SCCs tended to subvert the traditional dominant role of males in the Marakwet society.

The following strategies were suggested by the respondents to enhance male participation in SCCs:

- Introducing a portfolio of self-reliance projects such as mobile clinics, animal husbandry and poultry farming to help SCCs run their activities without solely relying on financial contribution of members.

- Having well-trained catechists who teach truth about Christ and acting as a good example to others.

- Having various recreation activities in the Church as choirs, drama and concerts to arouse interest of attendance.

- Encouraging and embracing positive cultures and discarding those that retard faith.

- Encouraging appropriate vision leadership beginning from catechists.

- The data gathered from the respondents indicates how certain factors influence participation or non-participation in SCCs. The analysis underlined the fact that the attitude of the members towards these SCCs needs to change.

\section{REFERENCES}

1. Guiney, J. (1984). Comparing Basic Christian Communities in South America and Africa. African Ecclesiastical Review, 26, 178.

2. Vatican II. (1966). Pastoral Constitution on the Church in the Modern World Gaudium et Spes, December 7, 1965. $A A S, 58,1025-1120$.

3. Kalilombe, P. (1984). "From Outstations to SCC(s)," Spearhead, 83, 59-64. Eldoret: AMECEA Gaba Publications.

4. Ugeux, B., \& Levebre, P. (1995). The Small Christian Community and parishes. Nairobi: St. Paul's Publications Africa.

5. John Paul II. (1991). Encyclical Letter Redemptoris Missio, December 7, 1990. AAS, 83, 249-340.

6. John Paul II. (1995). Apostolic Exhortation on the Church in Africa, Ecclesia in Africa. Nairobi: Paulines Publication-Africa.

7. Okoth, Z. (1994). Small Christian Communities in Kenya. Africa Ecclesial Review (AFER), 36(4), 197-265. Eldoret: AMECEA Gaba Publications.

8. Bernard, J. C. (1998). Christian Community: Response to Reality. New York: Holt Rhinehart and Winston.

9. Bames, E. M. (Ed) (1990). Commentary of the Bible. Cambridge: Lutherworth Press.

10. McGarry, C. (1995). What Happened at the African Synod. Nairobi: Paulines Publications Africa.

11. Kiriswa, B. (1982). Small Christian Communities in a Kenyan Parish. AFER, 24(2), 190. 
12. Radoli, A. (1993). An Analysis of References to Small Christian Communities in the Instrumentum Laboris of 1994 African Synod. AFER, 3(3).

13. Kiwanuka Bishop. (1994). "Small Christian Communities," African Ecclesial Review (AFER), 36(4), $243-258$.

14. Halloran, O. (2002). Small Christian Communities: Vision and Practicalities. Dublin: The Columba Press.

15. Korir, C. K. (1994). The Lay Faithful. African Ecclesial Review (AFER), 36(4), 197-265. Eldoret: AMECEA Gaba Publications.

16. Mejia, R. (1990). The Church in the Neighborhood. Nairobi: St. Paul Publications Africa.

17. Ezukwu, E. (2006). A Listening Church: Autonomy and Communion in African Churches. Wipf and Stock Publishers.

18. Olozie, O. (2001). The Church in Mission in Light of Ecclesia in Africa. Nairobi: Paulines Publications.

19. Hebblethwaite, M. (1993). Base Communities: An Introduction. London: Geofrey Chapman.

20. Krejcie, R. V., \& Morgan, D. W. (1970). Determining Sample Size for Research Activities. Educational and Psychological Measurement, 30, 607-610.

21. The Law Society of Great Britain and Ireland. (1983). The Code of Canon Law. London: Collins Liturgical Publication. 